\title{
Immunity of International Organizations from the Perspective of International Law
}

\author{
Fatemeh Mihandoost ${ }^{1}$ \\ ${ }^{1}$ Department of Law, Semnan Branch, Islamic Azad University, Semnan, Iran \\ Correspondence: Fatemeh Mihandoost, Department of Law, Semnan Branch, Islamic Azad University, Semnan, \\ Iran. Tel: 98-912-926-9700. E-mail: Fatemehmihandoost@yahoo.com
}

Received: January 6, $2016 \quad$ Accepted: January 19, $2016 \quad$ Online Published: February 28, 2016
doi:10.5539/jpl.v9n1p41

\begin{abstract}
The purpose of this study is to identify the international immunity and its type. We also sought to evaluate the immunity of international organizations from the perspective of international law in this study. International organizations have immunity in the implementation of their programs and tasks. In fact, one of the principles of public international law is immunity that prevents the presence of a foreign state in state courts. In some cases, there is a possibility of cancellation of immunity and in other cases withdrawal of immunity is derived from a political mission. These cases include accepting to solve the commercial dispute through arbitration because contrary to the authority of the state judge, judgment to address the dispute is not one of the government figures; therefore, government summoned to court of arbitration is not considered as a violation of state sovereignty. In practice, immunity has changed over the time. In other words, immunity has been modified over time. Research method used in this article is a review of the literature and interviews with experts who examine and compare the rules and regulations and the existing notes at home and abroad, about the immunity of international organizations. In the current situation, international general discipline is contrary to this subject that the government or organization holding immunity, while being aware of that, definitely accepts the condition of turning to a referee, which attracts the other party's confidence, and then refers to immunity in some stage of inspection or while implementing the sentence. The legal concept of immunity, in general, is the sense that its owner is immune from prosecution, law enforcement, and government officials and they will not be able to chase the holder of such immunity.
\end{abstract}

Keywords: immunity, international organizations, international law

\section{Introduction}

Immunity is one of the most important issues of public international law. Immunity means that its holder is immune from the prosecution of government officials (Sadr, 2007), p. 40. The idea of immunity from legal process is, as a general rule, abhorrent to modern legal civilization (Tajudeen, 2013). In this research we look for better understanding and introduction of the types of international immunity and immunity of international organizations and also review the immunity of international organizations from the viewpoint of international law. International organizations are known as second subjects of international law (Murphy, 2006), p. 132. These organizations, that have a legal personality distinct from their constituent states, have the same property, funds, and employees regarding the performance of their duties as while they are on a mission in the member states or third countries and have the same immunities as diplomats (Pour Hashemi, 2001), p. 78. The number of Consulates members makes it the largest and most complicated international organisation (No, 1996), p. 21. An obvious example of these organizations is the United Nations that Iran has joined it in the early years. Based on the customary rules of international law, government officials and leaders have immunity from foreign jurisdiction. Immunity from foreign discretion includes two types: personal and occupational immunity. Occupational immunity covers activities conducted by a public official in the performance of his functions and is based on state sovereignty. Personal immunity caused by customary international law is the oldest form of immunity. This type of immunity has temporary nature; i.e, it starts when the office is taken and stops when the office is abandoned (Bröhmer, 1999), pp. 361-371. Stability of existing agreements is the major means of immunity at the disposal of international oganisations (Mato, 2012), pp. 33-35.

In public international law to ensure the proper implementation of political and consular duties, some privileges 
have been granted to a foreign state and its diplomatic and consular representatives called immunity which has two views. According to one of the two views, the sanctity of the legal person of government as well as representatives, the political government and political correspondence is inviolable. According to the other view, the above are also outside the scope of judicial and administrative prosecutions of the acceptor.

In simpler terms, impunity means that foreign diplomatic representatives cannot be invited to criminal court or civil court and executive immunity means that the verdict of criminal court against representative of residing foreign state is not applicable in another country. This verdict is also true about the property of foreign state and that of representative of foreign state (Abdullahi \& Mir Shahbiz, 2007), p. 24. In other words, by virtue of the theory of immunity, property, life and dignity of the representatives of foreign governments do not lie under the sovereignty of the host government, and in case of violation they will be prosecuted in their home country (Grant and McClanahan, 1989), p. 44. This type of immunity has public acceptance except that in terms of state power in the run has faced with different approaches, and the philosophy behind it is proper performance of diplomatic missions and compliance with the general principle of state sovereignty whereby no state should be tried by another state or another state's laws must not applied to it. The philosophy behind immunity is to maintain equality between the parties and the court's independence. If there is no immunity and a government litigates a claim against another government in its court, the equality of the parties and the independence of the court are ignored (Sadr, 1975), p. 73. The concept of immunity of heads of states has changed dramatically since the early twentieth century. The past decades have seen a shift in the doctrine of international organisation immunity (Akande, 2014), p. 143. Process of developments of immunity of heads of states from 1919 to this date, that has been noticed in the Treaty of Versailles in the Statute of the Court of Nuremberg, Tokyo, former Yugoslavia, Rwanda tribunal, the Special Court for Sierra Leone, the Statute of the International Criminal Court and international tribunals and national policies, makes it clear that at present the heads of states, in the case of war crimes and gross violations of human rights and international humanitarian law, have neither personal nor professional immunity. In other words, the heads of states will be held liable if they violate peremptory international rules (Kachouian Fini, 2009), pp. 1137-1164.

\subsection{Review of the Research Literature}

When we enter the judgment, the sentencing judgement and determining punishment is considered in a different way. Crime and punishment are the rules of public order and out of the authority of the referee (Reymond, 1985), p. 517. Therefore referee has no jurisdiction to issue criminal penalties (Note 1).

In legal matters, the judge is employed by the state government and he is a representative of the government. He settles disputes according to the laws passed by the government and through state laws he recognizes the nature of truth and the verdict and receives his salary from public funds. However, the referee is delegate of the two parties of conflict and investigates through legal principles accepted by the two parties by implementing laws other than those passed by the government and through the authority gained by the agreement of the parties and judges with their own costs. Therefore if the government is tried by a referee, its jurisdiction will not be threatened and there will be no problem for the sanctity of the jurisdiction of government. However, the trial of the government is hardly accepted even by the referee. In the basic and general rules of most countries, a number of restrictions are expected from the government to accept arbitration (Shaw, 1995), p. 37. For example, Article 139 of Iran's constitution stipulates: settlement of disputes concerning public funds or referring it to arbitration in each case is subjected to approval by the Council of Ministers and shall be notified to the Majlis (parliament).

In cases where a party is foreigner and in important domestic issues that must also be approved by parliament, the law determines important cases. It is similar to the act that has also been emphasized in the Public and Revolutionary Court Procedure Act (Civil Affairs) passed in 2001. In different countries there have been laws that faded over time and disappeared due to required time (Note 2).

By virtue of Article 22 of the constitution of the Islamic Republic of Iran, the dignity, life, property, rights, residence, and occupation of the individuals are inviolable except in cases sanctioned by law. Cases of administration of law are related to law enforcement and criminal convictions that have been passed in general laws. This general rule includes all those who reside in Iran. But use of the term "immunity" does not refer to this general rule.

In fact, the demand for security nature and purpose of the formation of a state and a government are the agreement of the nation on not attacking cases enumerated in Article 22 of the constitution of the Islamic Republic of Iran. The use of the term "immunity" is related to the exception specified in Article 22 of the constitution. It has been excluded except in cases sanctioned by law. 


\section{Method}

The method applied in this research is descriptive-evaluative. Unlike historical researches, descriptive studies investigate the present. This type of research describes and interprets the existing circumstances and relationships. These researches study the present situation of a phenomenon or subject and evaluative researches describe the situation of a phenomenon at a specific time. This method does not suggest any hypothesis and does not study the relationship between variables and does not have any suggestions for further research but merely describes the present situation.

The research method used in this article is a review of the literature and interviews with experts as well as examining and comparing the rules and regulations and the existing notes at home and abroad on the immunity of international organizations.

\section{Results}

\section{The concept of immunity}

Masuniat is a word that has been considered as an equivalent and a translation of the word "immunity" in the Persian legal literature. Masuniat is an infinitive that means to remain safe and secure. In terms of derivation, the word Masun is a past participle meaning protected. In Arabic language, wherever the root Sun is applied, the meaning of protection is hidden in it. Though this term is Arabic, Arab lawyers use words like honor, privilege, exception, exemption and custody as translations and equivalents of Immunity; however, the recent meaning is more common (Hamavi, 1996), p. 42. Mazaya is the plural form of Mazyyat and in terms of derivation it is a gerund meaning abundance, excellence, superiority and privilege. Mazyyat has also been derived from roots such as Myz, Maz, Mazu, and Mazy, all of which include a sense of superiority and privilege. Each word derived from the root Mazy includes a sense of superiority and perfection (Al-Monjad, 1973), p. 39.

The word Mazyyat in Persian and Arabic legal literature is used as a synonym of privilege derived from the Latin Privilegium. Privilege also means point, privilege, superiority and exemption in foreign languages (Martin, 2013), p. 107.

But in a legal sense, immunity generally means that its holder is secure from being prosecuted by law and government officials. In other words, law and its enforcement agents cannot pursue the person holding it (Ziaee Bidgoli, 2009), p. 38.

By advantages we mean that a number of concessions are given to someone that other people do not have the right to use (Sadr, 2007), p. 40. There has been a lot of debate and controversy over the difference between immunity and privilege from the point of view of diplomatic law. Prior to the 1961 Vienna Convention on diplomatic relations, governments used the term in a way that covered both immunity and privilege without considering a specific meaning of these two terms or regarding any difference between them. One of the issues disputed while tuning and reviewing Convention 1961 was the difference between immunity and privilege. Finally, the two terms were used in the Convention, but neither was a definition suggested nor the difference was pointed out. Another same procedure was followed in setting up diplomatic rights conventions. In these conventions, that will be introduced in the following sections, immunities on topics such as personal inviolability, immunity from prosecution (criminal or civil), immunity from enforcement action and "benefits" in cases such as financial benefits, taxes and customs, exemption from audit and inspection, insurance of social services have been used.

It seems that this distinction aims to facilitate the discussion and formulation and it is a difference in form, not a scientific division, and international conventions framers deliberately did not enter these fruitless conflicts. The main difference is that immunity is directly related to international law unlike the benefits that the civil law of the countries has extensive competence in this regard on the basis of reciprocity behavior. Therefore, if benefits are taken advantage of, governments can limit such privileges according to their internal rules (Beigzadeh, 2013), p. 16. But this is not the case about immunity. The present article undertakes examining it.

\subsection{Types of Immunity}

International organizations in accordance with the principles of international law have impunity including immunity from prosecution, occupational safety, and immunity from prosecution (Mostafa \& Azar, 2015), pp. 12-23. Each of them will be discussed in the following sections.

\subsubsection{Judicial Immunity}

The word immunity means protection and preservation, and in the legal term it is mentioned that the prosecution of individuals is carried out with certain formalities due to their specific social, political, or legal tasks (Azhar \& 
Masjed Araei, 2012), pp. 54-62. This term includes all forms of exercising administrative authority. In other words, it includes all judicial processes from the beginning of judgment to sentencing trial, run and funding actions (Aghaei, 2003), p. 20. Executive Judicial immunity also means that its holders are outside the scope of executive power of government (Cassese, 2008), p. 156. For example, political representatives of foreign countries living in the Islamic Republic of Iran cannot be prosecuted in Iran, which is called political immunity, and the members of Islamic Consultative Assembly cannot be prosecuted or detained because of the views they have expressed in parliament or the votes they have given as their task as representatives, which is known as parliamentary immunity. The prosecution of judges follows a specific procedure which is called judicial immunity.

The purpose of identifying these privileges and immunities is not to help these individuals benefit and not punish them, but to provide good performance of their duties. For this purpose, certain basic procedures to prosecute some people have been predicted. These procedures are not identical for all the individuals in the above categories and differ according to the nature of their job in each class. In order to ensure justice and avoid unnecessary attacks to justice, especially the abuse of the holders of wealth, power, and force as well as professional bandits and criminals, legislator has determined two types of immunity for judges (Shamloo Ahmadi, 2004), p. 143.

\subsubsection{Occupational Immunity}

Job immunity means that the staff has immunity in the implementation of programs and targets (Foakes, 2011), pp. 3-16. Occupational immunity is related to the activities carried out by the government officials in order to implement their official duties. When the employee loses his job, he will not be prosecuted for these acts since he has done them in order to carry out his official duties and in fact he has acted within the framework of his official authority.

In addition, the liabilities are attributable to any foreign government, namely have universal effects. This type of immunity includes all actions of the staff, both formal and practical actions, and any legal liability related to the operation is held by the government (Cassese, 2002), pp. 853-875. But this should not be interpreted broadly and any action should not be taken as immunity. Immunity has validity to the extent that it does not violate the rules and principles and it is carried out according to the principles of international law (Asgari, 2009), p. 168.

\subsubsection{Immunity from Prosecution}

State organizations immunity from criminal prosecution has attracted a lot of attention in international and domestic criminal courts. A large number of studies have also been conducted on it (Bahman Taji \& Fallah Nasiri, 2015), pp. 37-64. The prosecution of some individuals is carried out through special procedures due to the specific social, political, or legal tasks they are responsible for and some are immune from criminal prosecution (Ashouri, 1999), p. 33.

Immunity from prosecution is, in fact, complementary of occupational immunity and briefly means that judicial officials cannot be prosecuted without the consent of the Desciplinary Supreme Court of Judges and before taking away the judicial immunity (Cassese, 2002), pp. 853-875. When an employee gets involved in activities in an organization, he might violate the purposes specified and his behavior may lead to crime. If we want to punish individual offenders, performing punishment will be hard since the people working in international organizations have different nationalities. We are also likely to get far from activities specified by the organization while we are punishing the offenders, which would be contrary to the goals of the organization. But for this purpose, the staff of international organizations has immunity from prosecution (Sour Israfil, 1999), p. 25 .

\subsection{Abuse of Immunities}

In a report from 1982 to 1988,147 heavy crimes have been committed in Washington by international organizations. 30 cases were committed by diplomats and 60 cases were related to their dependents and the other 57 cases were related to other members of the international organizations missions (Ben-Asher, 2000), p. 49. One of the most recent issues of international law in the field of rights of international organizations is taking advantage of the immunity of international organizations (Najdi Manesh, 2012), pp. 250-258. Any right is recognized and supported in order to be benefited properly. It is quite natural that if it is abused and not exploited properly, the first negative consequence will be a request to limit it and abuse of diplomatic immunity will not be the exception to this rule (Mirmohammadi, 2002), pp. 133-165. In the following we will introduce and examine some examples of misuse. 


\subsubsection{Misuse of Mission Areas}

Places of missions are defined as the buildings or parts of buildings and the land attached to them used to carry out the mission of the government as well as the residence of the head of the mission (Note 3).

There will be no difference in legal status of these mission places whether they are in ownership or lease. The immunity of places of mission has been mentioned in the same way in all the conventions on diplomatic law (Asadollahi, 1994), p. 41. On top of that, according to Article 23 of the Convention 1975, the host government is responsible to prosecute and punish the perpetrators if places of mission are attacked.

The subject as to whether the immunity of places of mission is absolute or useful caused severe disagreement between the governments participating in the 1961 Vienna Conference. Finally the conference did not come to a conclusion and just mentioned the two aforementioned principles of "respect for the laws of the host state" and "non-interference in internal affairs" and also advised "not using places of mission contrary to the duties of the mission" (Al Bakri, 1986), p. 29. The disagreement stemed from the fact that the governments would demand proper guarantees in case the immunity of places of mission was misused.

\subsubsection{Immunity of Residence}

Private accommodation and housing of heads of mission and board of deligates and its staff have the same immunity and support as those of places of mission (Note 4). The immunity of housing and the property belonging to it must be considered as functions of personal immunity, but because the immunity of residence has a situation similar to that of mission places and housing of the head of the mission is usually located at the headquarters of the mission (Mirmohammadi, 2002), pp. 133-165., it is discussed while discussing places of mission. In fact, immunity of place of residence is the sequence of personal immunity because the ambassador's independence and his confidence are impaired by lack of immunity of his residence. Then he will not be able to perform the important tasks he is responsible for. However, if the holders of immunity use their private housing in a way that is inconsistent with their duties, the receiving state must be protected against these abuses because obviously immunity of housing does not mean violating and ignoring the regulations of the host government.

\subsubsection{Misuse of Personal Immunity}

Historically, personal immunity is seen as the first rule of international law (Nascimento, 1973), p. 182. Although there is no definition of consensus about personal immunity, everyone is in agreement on the results of this immunity, i.e., the lack of arrest and detention and prevention from any action against political officials (Shami, 1994), p. 61. On the other hand, International Court of Justice in the case of United States diplomatic and consular staff in Tehran said that the immunity of the members of the mission and its staff will not mean that committing the crime or violence is free for political officer and his arrest for the prevention of crime is not possible in the short term(Gross, 1980), p. 395.

\subsubsection{Misuse of the Diplomatic Bag}

Using diplomatic bag today is very important in providing governments relationships with their representatives abroad. The last document of diplomatic law (Note 5) was developed in response to the importance, and legal rules of bags and messengers have been completed in the other conventions. Since this Convention is at the design stage (United Nations, 1996), p. 58, the rules of the bag must be sought in other conventions. The most important issues concerning the diplomatic bag or suitcase are taking advantage of them and the problem of the bag inspection (Gove, 1981). If the authorities of the host government get suspicious about what is inside the bag and consider the possibility of the suspect bag containing prohibited objects such as trafficking or arms, are they able to inspect and audit it? With regard to international practice, a lot of abuse from diplomatic bags is seen. Rich countries abuse the immunity of the bag for embedded weapons, hand bombs, firearms, dangerous chemicals, information exit, stealing of artefacts and so on. In contrast, poor countries are mainly involved in smuggling alcohol, currency and drugs. In total, a variety of items from human to dead body have been found in diplomatic bags.

\section{Discussion}

As long as law governs, immunity exists but it is shaken upon exiting the rule of law and entering the rule of will. Immunity makes sense in accordance with the framework of existing laws governing the public. As a result, immunity loses its meaning if these regulations are not enforced due to rebellion or through agreement. Immunities are granted to the international organizations and their staff in order to enable them to perform the designated tasks confidently. Immunity holders have a duty to respect the laws and regulations of the host government and refrain from interfering in the internal affairs of that State. If they do not observe these two principles and engage in acts that are contrary to their duties, they have misused the granted immunities. 
Deportation as an undesirable person, taking away optional immunity, and cuting off diplomatic relations are the traditional guarantees for misusing immunities. But with the expansion and diversification of the cases of abuse, a number of cases such as the intensity of the action in introducing the individual as an undesirable person, taking away mandatory immunity, reducing the number of members of diplomatic missions and the development of compulsory insurance can be considered in reducing or preventing from abuses. It should be noted that dealing with the issue of immunity of government and independent international organizations is different in developing and developed countries.

Although the traditional rules of judicial and executive immunity are still implemented in the Third World and foreign embassies can hire employees and workers and exploite labor and services and then refuse to pay their salaries and perks specified in the domestic laws of the host country by referring to immunity and even sometimes the members of embassies refuse to pay for the dinner they had at a restaurant or driving ticket in case of not observing traffic rules and if somebody sues them they will refuse to go to the court and accept the verdict, developed countries are moving toward the principle of the responsibility and exception of immunity of government and independent international organization by abandoning the principle of immunity. In the case of the company called Keihan Felez TOUS, UNICEF, referring to immunity and refusing to implement the sentence and issuing the order of the removal of the ban on commercial bank accounts of the convicted that has been sentenced to pay in connection with commercial issues were so surprising that legislators are recommended to improve the regulations and pay more attention to the coordination with the world trade.

\section{References}

Abdullahi, M., \& Mir Shahbiz, S. (2007). The state judicial immunities under international law (2nd ed.). Iran: Presidential Press Office.

Aghaei, D. (2003). international organizations (1st ed.). tehran: righteous generation.

Akande, R. A. (2014). Enforcement and Practicability of Sovereign Immunity Doctrine in International Commercial Arbitration. J. Pol. \& L., 7, 143. http://dx.doi.org/10.5539/jpl.v7n2p143.

Al-Bakri, A. (1986). diplomatic and consular relations, the founder of the University (1st ed.). beirut.

Al-Monjad. (1973). in the language and flag: East House, Beirut.

Asadollahi, M. (1994). revival of capitulation and its consequences (the Islamic Propagation Organization ed.). iran.

Asgari, P. (2009). Jurisdictional Immunities of States and enforcement of arbitral awards on investment by focusing on the 1965 Washington Convention. Leiden Journal of International Law, 9(1), 168.

Ashouri, M. (1999). Criminal Procedure Code (1st ed.; Vol. 2). tehran: samt.

Azhar, Z., \& Masjed Araei, M. (2012). International non-governmental organizations and human rights immunity functions, 54-62.

Bahman Taji, S., \& Mir Fallah Nasiri, N. (2015). Foundations and impacts approach International Court of Justice in the case of Hissène Habré in the abolition of immunity heads of state criminal (former President of Chad). study of criminal law, (1), 37-64.

Beigzadeh, E. (2013). Immunity of States and international organizations in the light of developments in international law.

BEN-ASHER, D. R. O. R. (2000). Human Rights Meet Diplomatic Immunities: Problems and Possible Solutions.

Bröhmer, J. (1999). Diplomatic Immunity, Head of State Immunity, State Immunity: Misconceptions of a Notorious Human Rights Violator. Leiden Journal of International Law, 12(02), 361-371. http://dx.doi.org/10.1017/S0922156599000151

Cassese, A. (2002). When may senior state officials be tried for international crimes? some comments on the Congo v. Belgium Case. European Journal of International Law, 13(4), 853-875. http://dx.doi.org/10.1093/ejil/13.4.853

Cassese, A. (2008). The Human Dimension of International Law: Selected Papers of Antonio Cassese. Oxford University Press. http://dx.doi.org/10.1093/acprof:oso/9780199232918.001.0001

do Nascimento Silva, G. E. (1973). Diplomacy in international law. Sijthoff \& Noordhoff International Publishers.

Foakes, J. (2011). Immunity for International Crimes?. Developments in the Law on Prosecuting Heads of State in Foreign Courts [online]. 
Gove, P. B. (1981). Webster's third new international dictionary of the English language, unabridged (Vol. 1). Merriam-Webster.

Gross, L. (1980). Case Concerning United States Diplomatic and Consular Staff in Tehran: Phase of Provisional Measures. The. Am. J. Int'l L., 74, 395. http://dx.doi.org/10.2307/2201507

Hamavi, M. (1996). diplomatic terms. beirut: tailor.

Kachouian Fini, J. (2009). The transformation of the heads of state immunity in international criminal law. Foreign Policy Journal, 23(4), 1137-1164.

Martin, E. (2013). A Dictionary of Law (7th ed.). Oxford University Press.

Mato, H. T. (2012). The Role of Stability and Renegotiation in Transnational Petroleum Agreements. Journal of Politics and Law, 5, 33-35. http://dx.doi.org/10.5539/jpl.v5n1p33

McClanahan, G. V. (1989). Diplomatic immunity: Principles, practices, problems. New York: St. Martin's Press.

Mirmohammadi, S. M. (2002). Abuse of diplomatic immunities and enforcement of international law. magazine: a useful, 33, 133-165.

Mostafa, B., \& Azar, K. (2015). immunity of delegations of States to international organizations. Paper presented at the the first international conference on human rights and sustainable development of civil society, Shiraz.

Murphy, S. D. (2006). Principles of international law. West Group.

Najdi Manesh, H. A. (2012). State immunity and jus cogens in international court procedures. Paper presented at the international conference Immunity of international organizations, Tehran, 47(5), 250-258.

No, T. S. (1996). Agreement on Implementation of Article VI of the General Agreement on Tariffs and Trade 1994.

Pour Hashemi, A. (2001). set rules and regulations of international law: Majd.

Reymondm, C. (1985). souveraineté de l'Etet et participation a l'arbitrage, Rev. arb.

Sadr, J. (1975). diplomatic and consular law: Center for International Studies.

Sadr, J. (2007). diplomatic and consular law Tehran: print publications Institute of Tehran University.

Shami, A. H. (1994). diplomacy, science home to millions (2nd ed.). beirut.

Shamloo Ahmadi, M. H. (2004). prosecution and preliminary investigation (Vol. 1). isfahan: Isfahan assistants.

Shaw, M. (1995). International Law. tehran: information dissemination.

Sour Israfil, M. (1999). Confusion meant privileges and immunities under international law, a reflection on the definitions and concepts. (25).

Tajudeen, I. O. (2013). Executive Immunity in Nigeria: Putting Off Old Garments. J. Pol. \& L., 6, 189. http://dx.doi.org/10.5539/jpl.v6n3p189

United Nations. (1996). The work of International Law Commission, united nations (5th ed.). Newyork.

Ziaee Bidgoli, M. R. (2009). Public International Law: a treasure of knowledge.

\section{Notes}

Note 1. Article 487 Criminal Procedure Code public and revolutionary courts (in civil cases), adopted on 1999.

Note 2. Article 2060 of the Civil Code French.

Note 3. Rules Collection, 1987.

Note 4. Article 2060 of the Civil Code French.Rules Collection, 1987.

Note 5. the 1989 Convention.

\section{Copyrights}

Copyright for this article is retained by the author(s), with first publication rights granted to the journal.

This is an open-access article distributed under the terms and conditions of the Creative Commons Attribution license (http://creativecommons.org/licenses/by/3.0/). 